\title{
Glacier naled evolution and relation to the subglacial drainage system based on water chemistry and GPR surveys (Werenskioldbreen, SW Svalbard)
}

\author{
Łukasz STACHNIK, ${ }^{1,2}$ Jacob C. YDE, ${ }^{2}$ Marta KONDRACKA, ${ }^{3,4}$ Dariusz IGNATIUK, ${ }^{3,4}$ \\ Magdalena GRZESIK ${ }^{3}$ \\ ${ }^{1}$ Institute of Geography and Spatial Management, Jagiellonian University, Kraków, Poland \\ E-mail: I.stachnik@uj.edu.pl \\ ${ }^{2}$ Sogn og Fjordane University College, Sogndal, Norway \\ ${ }^{3}$ Institute of Geophysics, Polish Academy of Sciences, Warszawa, Poland \\ ${ }^{4}$ Faculty of Earth Sciences, University of Silesia, Poland - Centre for Polar Studies KNOW (Leading National Research \\ Centre), Sosnowiec, Poland
}

\begin{abstract}
Glacier naledi are extrusive ice masses that appear in front of glaciers as a consequence of refreezing of meltwater seepage during the accumulation season. These structures provide a unique opportunity to understand subglacial drainage activity during the accumulation season; however, only few detailed studies have previously focused on their characteristics. Here, we investigated glacierderived naled assemblages in the proglacial zone of the polythermal glacier Werenskioldbreen $\left(27.4 \mathbf{~ k m}^{2}\right)$ in SW Svalbard. We determined the spatial distribution of naledi using ground penetrating radar surveys. The main subglacial drainage pattern was related to a channel under the medial moraine, and three sources are linked to a distributed subglacial drainage network. The relation between atmospherically-corrected $\left(\mathrm{Ca}^{2+}+\mathrm{Mg}^{2+}\right)$ and $\left(\mathrm{SO}_{4}^{2-}\right)$ in sub-naled waters was closely related to sulphide oxidation coupled with carbonate dissolution $(r=0.99$; slope $=1.6)$. This is consistent with the local lithology, which is dominated by schist containing carbonates. We also found high carbonate saturation indices in pale white ice layers within the naled. We conclude that sulphide oxidation coupled with carbonate dissolution is the dominant chemical weathering process in the subglacial drainage system of Werenskioldbreen during the accumulation season.
\end{abstract}

KEYWORDS: glacier chemistry, glacier hydrochemistry, ground-penetrating radar, ice chemistry, meltwater chemistry

\section{INTRODUCTION}

Glacier naledi (singular naled; also referred to as icings or aufeis) are dome- or cone-shaped ice bodies formed adjacent to glacier fronts during the accumulation season, as a consequence of rapid freezing of subglacial meltwater seepage mixed with snow (Åkerman, 1982; Wadham and others, 2000). The subglacial water involved in this process derives from the drainage system of polythermal glaciers (Wadham and others, 2000) or from water routed through saturated subglacial sediments beneath cold-based glaciers (Hodgkins and others, 2004). Glacier naledi are able to influence their surrounding environment at different spatial and temporal scales. For example, cryofreezing occurring during naled formation results in solute enrichment, which can lead to chemical precipitation in ice lattices and water beneath naled assemblages (Pollard, 2005; Yde and others, 2012). Also, Wadham and others (1998) suggested that during the early ablation season solutes released from storage in naled may cause a periodically increased solute delivery to fjords and coastal areas.

During the accumulation season, minerals precipitate due to freezing of highly concentrated solutions within naled ice. For example, calcite tends to precipitate closer to the outflows, causing ion depletion in $\mathrm{Ca}^{2+}$ and $\mathrm{HCO}_{3}^{-}$downstream from the naled (Wadham and others, 2000). Mineral precipitates are observed on top of naled surfaces (Yde and others,
2012), in distinct layers within naled (Yde and Knudsen, 2005) and at the bottom of naled assemblages (Pollard, 2005). Most studies on glacier naled have been conducted during the ablation season, when the naledi are rapidly melting (e.g., Drozdowski, 1982; Bukowska-Jania, 2007), potentially hampering determination of the spatial distribution of naled at the end of the accumulation season. At present, analyses of crystallographic and chemical data from vertical naled profiles, which allow determining their evolution, have only been conducted during the ablation season (Yde and others, 2012), when the ice crystallography in some layers of the naled may change from solid ice to candle-type structures (Drozdowski, 1982; Hodgkins and others, 2004).

Chemical weathering beneath naledi is believed to increase ion concentrations due to slow water flow, allowing a long time for water/mineral interactions (Gokham, 1987; Yde and others, 2012). At Finsterwalderbreen in Svalbard, Wadham and others (2000) showed that sulphide oxidation and calcite precipitation are widely occurring chemical reactions during the accumulation season. Additional reactions, including hydrolysis and ion exchange, may also influence ion concentrations and cause $\mathrm{Ca}^{2+}$ enrichment over $\mathrm{Na}^{+}$ (Wadham and others, 2000). However, local lithology plays a controlling role in the chemistry of naled water. For example, Yde and others (2012) found that calcite 
carbonation was the predominant chemical reaction at Austre Grønfjordbreen in Svalbard during naled formation.

Studies on naled morphology are often focused on their development at different spatial scales varying from the near-glacier environment (Olszewski, 1982; Grześ and Sobota, 2000) to the proglacial area (Wadham and others, 2000) or regional scales (Bukowska-Jania and Szafraniec, 2005). Investigations have shown that glacier naled thickness depends on topographic characteristics (Gokham, 1987), presence of ridges in bedrock (Olszewski, 1982) and glacier size (Bukowska-Jania and Szafraniec, 2005). Domeor cone-shaped mounds on the naled surface are common (Carey, 1973; Hodgkins and others, 2004). However, at present only few studies have examined how the sub-naled topography determines the spatial variation of naled assemblages (Moorman and Michel, 2000).

Here, we analyse the hydrological activity of the subglacial drainage system during the accumulation season of the polythermal glacier Werenskioldbreen. We use ground penetrating radar (GPR) surveys and chemical analyses to assess the distribution and growth of the proglacial naledi, the linkage between naled formation and the subglacial drainage system and the chemical weathering processes occurring in the subglacial environment of Werenskioldbreen during the accumulation season.

\section{STUDY AREA}

Werenskioldbreen $\left(77^{\circ} 05^{\prime} \mathrm{N}, 15^{\circ} 15^{\prime} \mathrm{E}\right)$ is located in SW Svalbard (Fig. 1) and covers an area of $27.4 \mathrm{~km}^{2}$. It is a land-terminating, valley-type polythermal glacier, $9.5 \mathrm{~km}$ long and having an altitude range from 60 to $650 \mathrm{~m}$ a.s.l. (Hagen and others, 1993). Werenskioldbreen has receded and the glacier surface at the front has lowered by $28.7 \mathrm{~m}$ from 1958 to 1990 (Grabiec and others, 2012). The glacier has a surface layer of cold ice 50-100 m thick above a temperate ice layer (Pälli and others, 2003). At the snout the glacier is frozen to the bedrock, and this cold-based zone extends to a distance of $0.7-1 \mathrm{~km}$ up-glacier (Pälli and others, 2003). In the proglacial zone, the area occupied by naled has changed from $0.5 \mathrm{~km}^{2}$ in 1957 (Baranowski, 1982) to $\sim 0.4 \mathrm{~km}^{2}$ in 1999 (Bukowska-Jania, 2007). The naledi are separated into four different parts close to the glacier front. These are referred to as Kvisla, Medial moraine, Central and Angell (Figs 1 and 2). The drainage system of Werenskioldbreen is subject to interannual

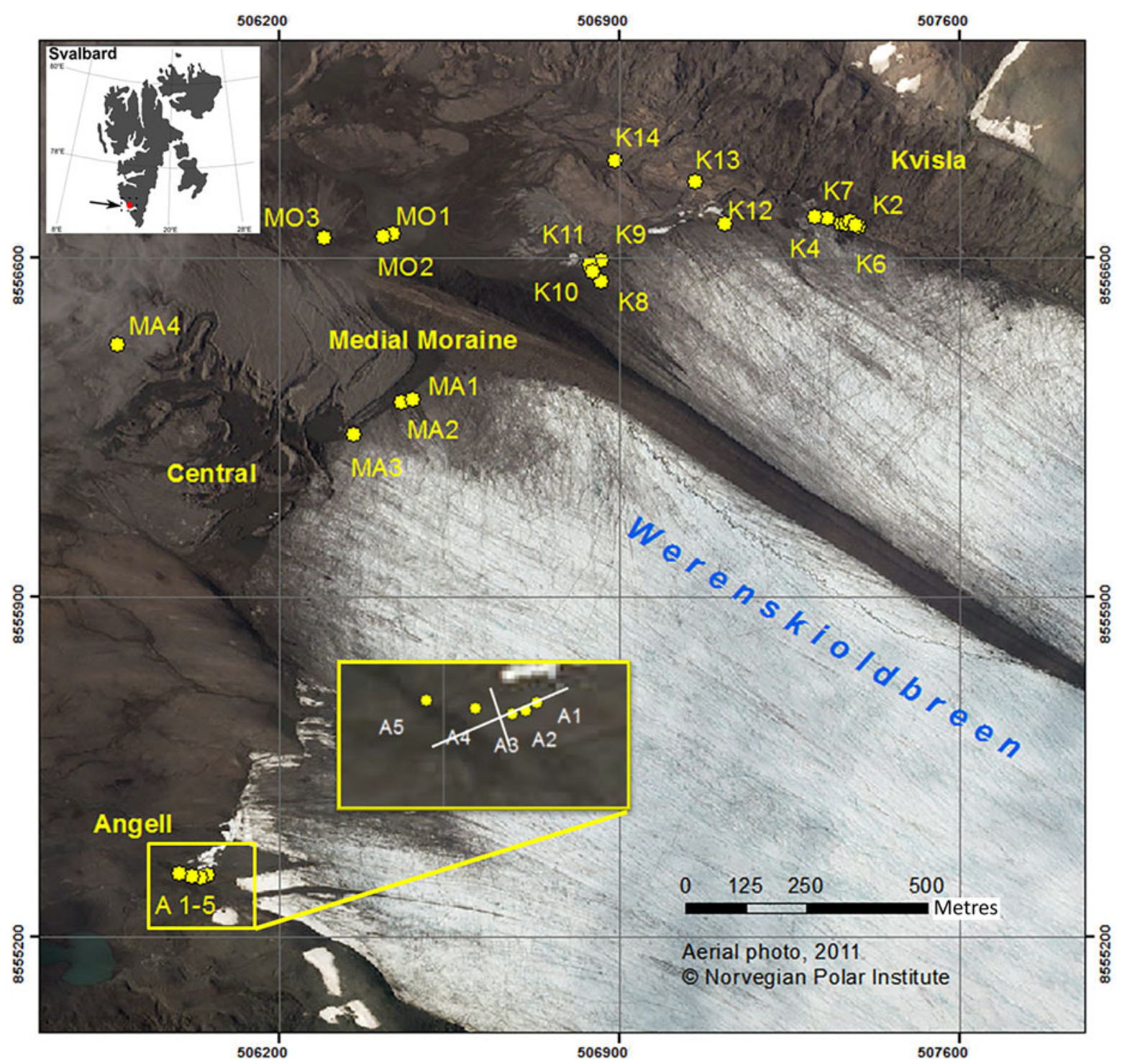

Fig. 1. Map showing the sampling sites (yellow dots) and an example of two GPR profiles (white lines) in front of Werenskioldbreen, Svalbard. Orthophoto from the Norwegian Polar Institute (http://toposvalbard.npolar.no/), 25.07.2011. 

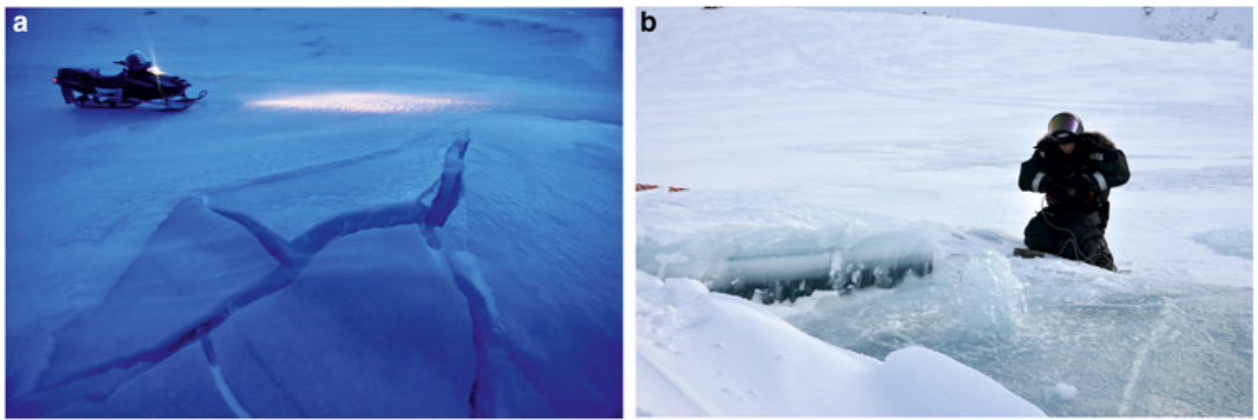

Fig. 2. Naled mounds with cracks in their crest situated at (a) Kvisla and (b) Angell. Note the broken crest of naled and geyser-type outflow.

variations (Stachnik and others, submitted), where the main outflow either occurs at the Kvisla or central sections of the glacier terminus, and minor outflows occur at the Angell section (Fig. 1).

Geologically, the bedrock belongs to the Hecla Hoek succession, formed in the contact zone between three Proterozoic tectonic blocks (Czerny and others, 1993). Rocks belonging to the Eimfjellet group, consisting of amphibolite, quartzite and chlorite schist are found beneath the southern part of the glacier. The eastern areas of the glacier are located above bedrock of the Deilegga group, comprising mainly phyllites with quartzite and silt intercalations, and calcareous and chlorite schists. Pyrite accompanied by pyrrhotite, galena, sphalerite and haematite are the most common ore minerals. Carbonate minerals are present as dolomite and Fe-calcite, and occur in both the Deilegga and Eimfjellet groups (Czerny and others, 1993). Proglacial sediments are composed of $>7 \%$ of calcium carbonate, although the content of calcium carbonates increases up to $47 \%$ in glacio-fluvial sediments close to naledi in the central parts of the glacier forefield (Bukowska-Jania, 2007).

At the Polish Polar Station in Hornsund, which is situated $\sim 12 \mathrm{~km}$ to the SE from the study area, mean daily air temperatures were generally below $0^{\circ} \mathrm{C}$ from the beginning of November 2012 to mid-May 2014 (Hornsund GLACIOTOPOCLIM database). During this period, positive mean daily air temperatures were only measured six times.

\section{METHODS}

\section{Ground penetrating radar surveys}

GPR surveys were performed using a RAMAC/GPR CUII system with shielded $800 \mathrm{MHz}$ antenna (MAL $\AA$ Geo Science) and a GPS receiver (Leica) (Figs 3 and 4). In total, ten longitudinal and transverse profiles were conducted on naled in the area of Angell on 24 March 2013. Two of the
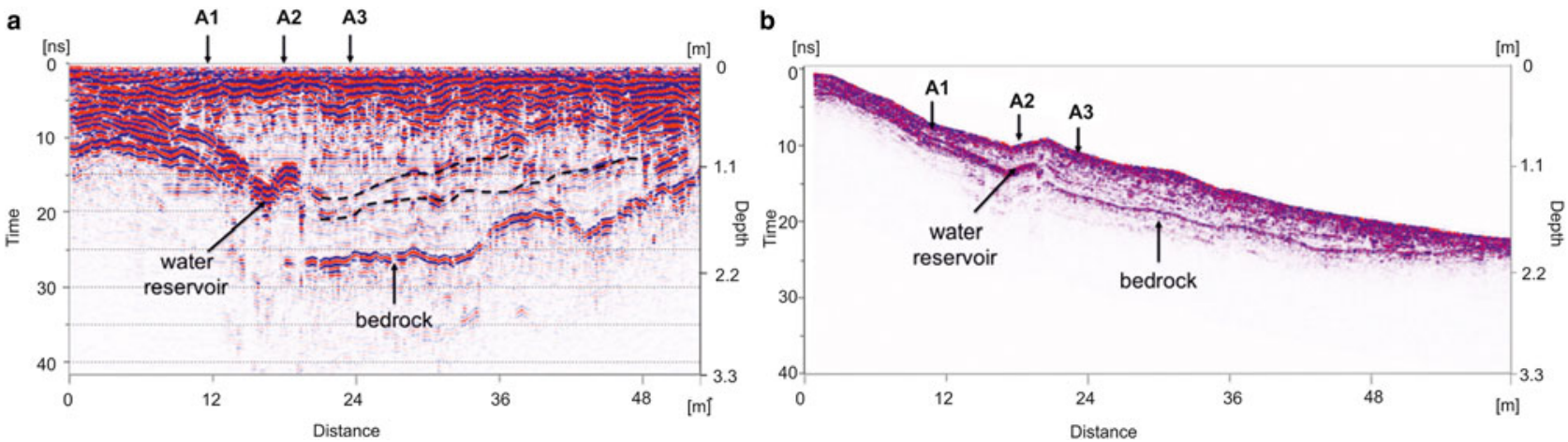

Fig. 3. Longitudinal GPR profile through naled in the Angell section of the Werenskioldbreen forefield. (a) Profile along the naled assemblage. The dashed lines indicate stratification within the accumulated naled ice. (b) Topography-corrected profile along the naled assemblage.

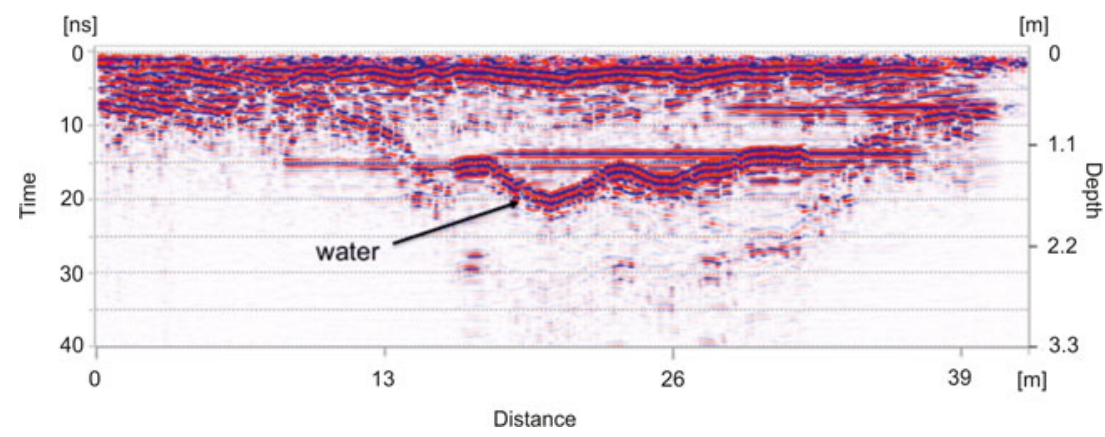

Fig. 4. Transverse GPR profile through naled in the Angell section showing water beneath naled mounds (perpendicular to point A2). 
profile transects are presented in Fig. 1. Processing and interpretation of the data were performed using the RadExplorer software package (DECO Geophysical Ltd), applying the direct current and background removal processing routines. The model was based on a dielectric constant and electromagnetic wave propagation velocity of $\varepsilon=4$ and $v=15$ $\mathrm{cm} \mathrm{ns}^{-1}$, respectively (Figs 3 and 4) (Plewes and Hubbard, 2001).

\section{Naled ice and water sampling}

We collected naled ice and water samples during four fieldwork campaigns between 1 February and 16 May 2013. The sampling sites were chosen along the glacier terminus and labelled according to the nearest outflow, which is known to be active during the ablation season (Fig. 1).

We collected 19 samples of sub-naled water in precleaned (five rinses using deionised water) polypropylene bottles (Angell, $N=3$; Kvisla, $N=9$; Central, $N=4$; and Medial moraine, $N=3$ ). Sub-naled water was absent in seven drillings ( $\mathrm{K} 1, \mathrm{~K} 5, \mathrm{~K} 8, \mathrm{~K} 9, \mathrm{~K} 11, \mathrm{~A} 3$ and $\mathrm{A} 5$ ).

We obtained 25 ice cores (width of $7.25 \mathrm{~cm}$ ) using a Kovacs Mark III ice drill at Angell $(N=5)$, Kvisla $(N=14)$, Central $(N=3)$, and Medial moraine $(N=3)$. For technical reasons, we were unable to obtain an ice core from MA1. In this paper, we provide examples of detailed descriptions of eight ice cores obtained from the Angell and Kvisla naledi. Each ice core was divided into a number of subsamples based on the layering of the naled.

\section{Laboratory analyses}

Ice samples were melted in the laboratory of the Polish Polar Station at Hornsund at room temperature. The samples were subsequently filtered using a Millipore vacuum filtration kit with $0.45 \mu \mathrm{m}$ Whatman filters. The $\mathrm{pH}$ and specific conductivity were measured using a multimeter ELMETRON CP-401. We analysed the water samples for major cations $\left(\mathrm{Ca}^{2+}\right.$, $\left.\mathrm{Mg}^{2+}, \mathrm{Na}^{+}, \mathrm{K}^{+}\right)$and anions $\left(\mathrm{SO}_{4}^{2-}, \mathrm{Cl}^{-}\right)$concentrations by ion chromatography (IC) using an ion chromatograph Metrohm Compact IC 761 with the detection limits of 0.5 , $0.8,0.4,0.3,0.2$ and $0.3 \mu \mathrm{eq} \mathrm{L}^{-1}$, respectively. IC ion concentration analyses were conducted with an accuracy level of $1 \%$. Concentrations of $\mathrm{F}^{-}, \mathrm{NO}_{3}^{-}, \mathrm{NO}_{2}^{-}, \mathrm{Br}^{-}, \mathrm{NH}_{4}^{+}$were below their detection limits. The samples were acidified prior to cation analyses.

Alkalinity (predominantly $\mathrm{HCO}_{3}^{-}$) was determined by automatic titration using a Metrohm 702 SM Titrino and acidified to $\mathrm{pH} 4.5$ (titration endpoint). We measured the $\mathrm{pH}$ simultaneously using a Unitrode glass electrode. The detection limit of the alkalinity measurements was $10 \mu \mathrm{eq} \mathrm{L}^{-1}$.

Analysis quality, measured as charge balance error (CBE), was estimated using the following Eqn (1):

$$
C B E=\frac{\sum X^{+}-\sum X^{-}}{\sum X^{+}+\sum X^{-}} \times 100 \%,
$$

where $X$ is ion concentration in meq $\mathrm{L}^{-1}, \sum X^{+}$is the sum of cations in meq $\mathrm{L}^{-1}$, and $\sum X^{-}$is the sum of anions in meq $\mathrm{L}^{-1}$. The CBEs had a mean value of $0.0 \%$ and ranged from $-6.5 \%$ to $4.8 \%$. One ice sample showed a high CBE value (A2); consequently, we altered the alkalinity for this sample by assuming that its alkalinity is equal to the charge balance.

\section{Statistical analyses}

We tested whether ion concentrations $\left(\mathrm{HCO}_{3}^{-}, \mathrm{SO}_{4}^{2-}, \mathrm{Cl}^{-}\right.$, $\left.\mathrm{Ca}^{2+}, \mathrm{Mg}^{2+}, \mathrm{K}^{+}, \mathrm{Na}^{+}\right)$in naled varied between Kvisla $(N=33)$, Angell $(N=21)$, Medial moraine $(N=6)$ and Central $(N=5)$. For this purpose we used a non-parametric Kruskal-Wallis test $(p<0.05)$ to identify whether there are differences in distribution parameters among the groups. We used ion concentrations and site as dependent and grouping variables, respectively. Whenever the KruskalWallis test showed a significant difference in at least one distribution, we used a post-hoc Dunn's test with Bonferroni's correction for multiple comparisons to identify which ion concentrations are statistically different. In this case, significant differences were considered to be for $p<0.10$, as the sample size varied considerably among sites, which could influence the median values and consequently influence the results of the Dunn's test. All statistical analyses were conducted using the Statistica software (version 12.0).

\section{Geochemical calculations}

In order to determine the fraction of solutes originating from chemical weathering, correction of water chemistry (marked by asterisks, i.e. ${ }^{*} \mathrm{SO}_{4}^{2-}$ ) was performed based on ion-to- $\mathrm{Cl}^{-}$ ratio in oceanic water (e.g., Holland, 1978).

The sulphate mass fraction (SMF) that distinguishes chemical weathering reactions was calculated using Eqn (2):

$$
S M F=\frac{{ }^{*} \mathrm{SO}_{4}^{2-}}{\left({ }^{*} \mathrm{SO}_{4}^{2-}+\mathrm{HCO}_{3}^{-}\right)},
$$

where ${ }^{*} \mathrm{SO}_{4}^{2-}$ is the concentration of sulphate, corrected for atmospheric input (in meq $\mathrm{L}^{-1}$ ), and $\mathrm{HCO}_{3}^{-}$is the concentration of bicarbonate (in meq $\mathrm{L}^{-1}$ ).

A SMF equal to 0.5 results from sulphide oxidation coupled to carbonate dissolution, whereas a SMF $<0.5$ suggests that carbonation of carbonate is the dominant reaction process (Wadham and others, 2000).

We estimated ice and water saturation indices (SI) associated with minerals such as halite, calcite, dolomite and gypsum, and partial pressure of $\mathrm{CO}_{2}$ using the PHREEQC software with the MINTEQ database (Parkhurst and Appelo, 2013). We used water $\mathrm{pH}$ measured in the laboratory and water chemistry as input data and previously described formulas (Yde and others, 2012). We assumed a water temperature of $0.01^{\circ} \mathrm{C}$ (Kies and others, 2011).

\section{RESULTS}

\section{Naled drilling}

Based on observations from drilling through the naled, the mean naled ice thickness was highest at the Angell site and lowest at the Central site. Naled thickness ranged from 0.31 to $1.72 \mathrm{~m}$ with a mean value of $0.83 \mathrm{~m}$. All sites showed a minimal thickness of $\sim 0.3-0.4 \mathrm{~m}$. The ice thicknesses of naledi in metres (number of cores; mean, minmax) ranged as follows: Angell $(N=5 ; 1.01,0.37-1.72)$, Kvisla $(N=14 ; 0.81,0.31-1.37)$, Central $(N=3 ; 0.64$, 0.40-0.80) and Medial moraine $(N=3 ; 0.81,0.47-1.07)$. 


\section{Chemical and typological stratification of ice}

The mean total dissolved solids (TDS) in ice differed depending on the section of the proglacial area considered: Kvisla $\left(2.5 \mathrm{meq} \mathrm{L}^{-1}\right)>$ Medial moraine $\left(1.5 \mathrm{meq} \mathrm{L}^{-1}\right)>$ Angell $\left(1.3\right.$ meq $\left.\mathrm{L}^{-1}\right)>$ Central $\left(0.7 \mathrm{meq} \mathrm{L}^{-1}\right)$. Major ions such as $\mathrm{HCO}_{3}^{-}, \mathrm{SO}_{4}^{2-}$ and $\mathrm{Ca}^{2+}$ also followed this sequence. The concentrations of $\mathrm{Ca}^{2+}$ and $\mathrm{SO}_{4}^{2-}$, the sum of cations excluding $\mathrm{Na}^{+}$and the sum of anions excluding $\mathrm{Cl}^{-}$were higher in Kvisla than in Angell (Tables 2 and 3). The sum of anions excluding $\mathrm{Cl}^{-}$and the sum cations excluding $\mathrm{Na}^{+}$were higher in Kvisla than in the Central sites (Tables 2 and 3). In addition, the $\mathrm{SO}_{4}^{2-}: \mathrm{HCO}_{3}^{-}$ratio was close to 1 in the Kvisla naled, whereas the mean $\mathrm{SO}_{4}^{2-}$ concentration was lower than $\mathrm{HCO}_{3}^{-}$by a factor of 2.5 in the Central and Angell naledi (Table 1).

Krustal-Wallis tests showed statistically significant $(p<0.05)$ differences in ion concentrations in ice for $\mathrm{SO}_{4}^{2-}, \mathrm{Ca}^{2+}$, $\mathrm{HCO}_{3}^{-}+\mathrm{SO}_{4}^{2-}$ and $\mathrm{Ca}^{2+}+\mathrm{Mg}^{2+}+\mathrm{K}^{+}$(Table 2). Also, sea-salt corrected ion concentrations $\left({ }^{*} \mathrm{TDS},{ }^{*} \mathrm{Mg}^{2+}\right.$, and ${ }^{*} \mathrm{Ca}^{2+}+$ ${ }^{*} \mathrm{Mg}^{2+}+{ }^{*} \mathrm{~K}^{+}+{ }^{*} \mathrm{Na}^{+}$), excluding $\mathrm{Na}^{+}$and $\mathrm{Cl}^{-}$ions in the cation and anion sums, respectively, appeared to be statistically different. Hence, we used $\mathrm{SO}_{4}^{2-}$ and $\mathrm{Ca}^{2+}$ concentrations, the sum of cations excluding $\mathrm{Na}^{+}$and the sum of anions excluding $\mathrm{Cl}^{-}$for a post-hoc Dunn's test. This test showed that significant differences $(p<0.10)$ occurred among the Angell, Kvisla and Central sites for $\mathrm{SO}_{4}^{2-}$ concentration, the sum of cations excluding $\mathrm{Na}^{+}$and the sum of anions excluding $\mathrm{Cl}^{-}$(Table 3). The concentrations of $\mathrm{Ca}^{2+}$ in Angell differed from Kvisla, whereas concentrations of $\mathrm{SO}_{4}^{2-}$ were different in Kvisla, Angell and Central sites. Sum of cations excluding $\mathrm{Na}^{+}$and sum anions excluding $\mathrm{Cl}^{-}$differ between Angell and Kvisla as well as between Kvisla and Central sites.

The highest concentrations of TDS were measured in the $\mathrm{K} 6$ ice core (4.9 meq $\left.\mathrm{L}^{-1}\right)$ at $1.07-1.37 \mathrm{~m}$ depth within transparent ice with a pale white layer, and in the A5 ice core (4.0 meq $\mathrm{L}^{-1}$ ) at $0-0.31 \mathrm{~m}$ depth in a mixed ice layer (Fig. 5). With the exception of the A5 and $\mathrm{K} 4$ ice cores, all ice samples had a total ion concentration below $1 \mathrm{meq} \mathrm{L}^{-1}$ in the top layer.

Naled ice also varied in their solute compositions (Fig. 5). In most ice profiles, ion concentrations increased with depth (A1, A4, K6, K14), although in two profiles (A5, K4) concentration decreased with depth. In the A3 profile, ion concentrations remained almost uniform throughout the entire profile. In Figure 6, granular, slush and candle ice are combined in the group called 'other types', whereas the occurrence of pale white and transparent ice within a single layer is referred to as a 'mixed' ice layer. In the sampled ice cores, layers of transparent and pale white ice dominated the typological stratification of the naled ice (Fig. 6). In general, the pale white layers were situated either in the upper (K4, A5) or lower (A1, K6, K14) parts of the profile. In the profiles of the $\mathrm{A} 3$ and $\mathrm{K} 13$ ice cores, granular ice was intersected by either transparent ice (A3) or candle ice (K13).

The stratification of the ice profiles depended on local conditions at the drilling site and the proximity to naled mounds. This was clearly exemplified by the sequence of ice cores A1-A5. In this case, ice types in ice cores located between the glacier margin and the naled mound (Figs 1 and 3) were mainly transparent ice with few thin pale white ice layers, whereas the ice types in ice cores located in the distal part of the naled showed frequent intercalations of pale white ice layers.

The SMF and median SI were higher for pale white and mixed ice types than for transparent ice and other ice types (Fig. 7). The SMF was higher for pale white ice than for other types of ice, reaching values of 0.5. Calcite SI was highest compared with the $\mathrm{SI}$ of other minerals, and was $>-1.5$ for the pale white and mixed ice types. Median SI for gypsum was higher than dolomite. Partial pressure of $\mathrm{CO}_{2}\left(\mathrm{pCO}_{2}\right)$ was at atmospheric level $\left(\mathrm{pCO}_{2}=-3.5\right)$ for all types of naled ice. Halite SI was $<-8.0$, which was the lowest SI measured compared with that of other minerals.

\section{Sub-naled water chemistry}

The TDS values for sub-naled water were ranked according to the sampling sites as follows: Central $\left(11.9 \mathrm{meq} \mathrm{L}^{-1}\right)>$ Medial moraine $\left(10.8 \mathrm{meq} \mathrm{L}^{-1}\right)>\operatorname{Kvisla}\left(8.9 \mathrm{meq} \mathrm{L}^{-1}\right)>$ Angell (5.2 meq $\mathrm{L}^{-1}$ ) (Table 4). The individual ion concentrations showed a similar pattern with only minor deviations. In the Central and Medial moraine sites, $\mathrm{SO}_{4}^{2-}$ concentrations were higher than $\mathrm{HCO}_{3}^{-}$concentrations. On the other hand, the $\mathrm{Ca}^{2+}$ concentration was highest in the Medial moraine area, whereas the $\mathrm{Ca}^{2+}$ concentrations were similar in the Kvisla and Central areas.

The concentration of ${ }^{*} \mathrm{Ca}^{2+}+{ }^{*} \mathrm{Mg}^{2+}$ appeared to be very closely related to ${ }^{*} \mathrm{SO}_{4}^{2-}(r=0.99)$ in the sub-naled water (Fig. 8). The slope of the best-fit regression line for these parameters was situated between the theoretical lines for sulphide oxidation and $\mathrm{Ca}-\mathrm{Mg}$ efflorescent salts dissolution. The Central (MA1, MA2) and Kvisla (K2) sites showed the highest concentrations of ${ }^{*} \mathrm{Ca}^{2+}+{ }^{*} \mathrm{Mg}^{2+}$ and ${ }^{*} \mathrm{SO}_{4}^{2-}$. Similarly, both of the sites in the Central area showed the highest SMF ( 0.55), $\mathrm{pCO}_{2}(\sim-2.6)$ and ${ }^{*} \mathrm{Na}^{+}+{ }^{*} \mathrm{~K}^{+}(>0.6$ meq $\mathrm{L}^{-1}$ ) values. Sites situated distal from the main outflow

Table 1. Naled ice ion concentrations (in meq $\mathrm{L}^{-1}$ ) in the proglacial area of Werenskioldbreen

\begin{tabular}{|c|c|c|c|c|c|c|c|c|c|c|c|c|c|c|c|c|c|}
\hline \multirow{2}{*}{$\frac{\text { Site }}{\text { Angell }}$} & \multirow{2}{*}{$\begin{array}{l}\text { Statistics } \\
\text { Mean }\end{array}$} & \multicolumn{2}{|c|}{$\mathrm{HCO}_{3}^{-}$} & \multicolumn{2}{|c|}{$\mathrm{SO}_{4}^{2-}$} & \multicolumn{2}{|c|}{$\mathrm{Cl}^{-}$} & \multicolumn{2}{|c|}{$\mathrm{Ca}^{2+}$} & \multicolumn{2}{|c|}{$\mathrm{Mg}^{2+}$} & \multicolumn{2}{|c|}{$\mathrm{K}^{+}$} & \multicolumn{2}{|c|}{$\mathrm{Na}^{+}$} & \multicolumn{2}{|c|}{ TDS } \\
\hline & & 0.37 & & 0.14 & & 0.11 & & 0.30 & & 0.19 & & 0.02 & & 0.12 & & 1.3 & \\
\hline$N=21$ & Min-max & 0.02 & 1.28 & 0.01 & 0.59 & 0.01 & 0.38 & 0.02 & 1.06 & 0.00 & 0.80 & 0.00 & 0.09 & 0.01 & 0.44 & 0.1 & 4.6 \\
\hline Kvisla & Mean & 0.59 & & 0.51 & & 0.15 & & 0.77 & & 0.33 & & 0.01 & & 0.17 & & 2.5 & \\
\hline$N=33$ & Min-max & 0.08 & 2.99 & 0.02 & 3.49 & 0.00 & 1.08 & 0.08 & 3.73 & 0.00 & 2.57 & 0.00 & 0.07 & 0.02 & 1.11 & 0.3 & 15.1 \\
\hline Central & Mean & 0.21 & & 0.07 & & 0.08 & & 0.22 & & 0.04 & & 0.00 & & 0.08 & & 0.7 & \\
\hline$N=5$ & Min-max & 0.05 & 0.43 & 0.03 & 0.15 & 0.02 & 0.22 & 0.05 & 0.51 & 0.02 & 0.08 & 0.00 & 0.01 & 0.02 & 0.22 & 0.2 & 1.3 \\
\hline MM & Mean & 0.46 & & 0.22 & & 0.08 & & 0.52 & & 0.15 & & 0.01 & & 0.09 & & 1.5 & \\
\hline$N=6$ & Min-max & 0.16 & 0.83 & 0.08 & 0.45 & 0.03 & 0.19 & 0.17 & 1.08 & 0.06 & 0.31 & 0.00 & 0.02 & 0.04 & 0.20 & 0.6 & 2.8 \\
\hline
\end{tabular}

MM, Medial moraine. 
Table 2. Comparison of ion concentrations in naledi at the Angell, Kvisla, Medial moraine and Central sites based on a Kruskal-Wallis non-parametric test. Bold value shows significant coefficients $(p<$ $0.05)$

\begin{tabular}{|c|c|c|c|}
\hline Ions & $P$ & lons & $p$ \\
\hline $\mathrm{HCO}_{3}^{-}$ & 0.08 & $\mathrm{Cl}^{-}$ & 0.79 \\
\hline $\mathrm{SO}_{4}^{2-}$ & 0.01 & $* \mathrm{SO}_{4}^{2-}$ & 0.00 \\
\hline $\mathrm{Na}^{+}$ & 0.84 & ${ }^{*} \mathrm{Na}^{+}$ & 0.87 \\
\hline $\mathrm{K}^{+}$ & 0.31 & $* \mathrm{~K}^{+}$ & 0.26 \\
\hline $\mathrm{Ca}^{2+}$ & 0.01 & $* \mathrm{Ca}^{2+}$ & 0.00 \\
\hline $\mathrm{Mg}^{2+}$ & 0.09 & $* \mathrm{Mg}^{2+}$ & 0.04 \\
\hline $\mathrm{HCO}_{3}^{-}+\mathrm{SO}_{4}^{2-}+\mathrm{Cl}^{-}$ & 0.06 & $\mathrm{Ca}^{2+}+\mathrm{Mg}^{2+}+\mathrm{K}^{+}+\mathrm{Na}^{+}$ & 0.06 \\
\hline Anions excl. $\mathrm{Cl}^{-}$ & 0.02 & Cations excl. $\mathrm{Na}^{+}$ & 0.02 \\
\hline TDS & 0.06 & TDS excl. $\mathrm{Na}^{+}, \mathrm{Cl}^{-}$ & 0.02 \\
\hline$* \mathrm{TDS}^{\mathrm{a}}$ & 0.02 & ${ }^{*} \mathrm{Ca}^{2+}+{ }^{*} \mathrm{Mg}^{2+}+{ }^{*} \mathrm{~K}^{+}+{ }^{*} \mathrm{Na}^{+}$ & 0.02 \\
\hline
\end{tabular}

a $*$ TDS is the sum of the following ions: $\mathrm{HCO}_{3}^{-}, * \mathrm{SO}_{4}^{2-}, * \mathrm{Na}^{+}, * \mathrm{Ca}^{2+}$, $* \mathrm{Mg}^{2+},{ }^{*} \mathrm{~K}^{+}$.

at Kvisla (K13, K14) and at Angell showed the lowest ion concentrations and low SMF and $\mathrm{pCO}_{2}$ indices.

In Figure 9, the $\mathrm{pCO}_{2}$ in sub-naled water is correlated to the ${ }^{*} \mathrm{SO}_{4}^{2-}$ concentration. All sites showed a $\mathrm{pCO}_{2}$ higher than the atmospheric level $\left(\mathrm{pCO}_{2}=-3.5\right)$. Concentration of $* \mathrm{SO}_{4}^{2-}$ increased along with the increase of $\mathrm{pCO}_{2}$ for all sites $(r=0.73)$. Two sites in the Central area (MA1, MA2) were characterised by the highest concentrations of $\mathrm{SO}_{4}^{2-}$ and $\mathrm{pCO}_{2}$. In Figure 10, it is seen that the concentration of ${ }^{*} \mathrm{Ca}^{2+}+{ }^{*} \mathrm{Mg}^{2+}$ increased along with $\mathrm{SMF}$, whereas the concentration of $* \mathrm{Na}^{+}+{ }^{*} \mathrm{~K}^{+}$showed no such tendency. Most ${ }^{*} \mathrm{Na}^{+}+{ }^{*} \mathrm{~K}^{+}$concentrations were below 0.4 meq $\mathrm{L}^{-1}$, with the exception of two sites in the Central area (MA1, MA2), where ${ }^{*} \mathrm{Na}^{+}+{ }^{*} \mathrm{~K}^{+}$concentrations exceeded $0.6 \mathrm{meq} \mathrm{L}^{-1}$. Remote naledi in Kvisla (K13, K14) and Angell showed lower SMF and concentrations of ${ }^{*} \mathrm{Ca}^{2+}+{ }^{*} \mathrm{Mg}^{2+}$ compared with other sites.

Table 5 shows the chemical indices of sub-naled water from different sections of the proglacial area of Werenskioldbreen. Water saturation with respect to halite (SIhal) was low, with a SI ranging from -8.4 to -7.7 . Dolomite and calcite SI showed that these components were close to saturation in the Kvisla, Central and Medial moraine naledi. Accordingly, the chemical index of $\left({ }^{*} \mathrm{Ca}^{2+}+\right.$ $\left.{ }^{*} \mathrm{Mg}^{2+}\right):\left({ }^{*} \mathrm{Na}^{+}+{ }^{*} \mathrm{~K}^{+}\right)$changed from the highest values in the Kvisla sites $(\sim 22.5)$ to the lowest values in the Angell sites $(\sim 9.0)$. The $\left(\mathrm{Ca}^{2+}+\mathrm{Mg}^{2+}\right): \mathrm{Cl}^{-}$index was also highest in Kvisla ( 7.6) and decreased below 6.5 for all other sites. Sub-naled water in the Angell and Central sites showed

Table 3. Comparison of ion concentrations in naled ice at the Angell, Kvisla, Medial moraine and Central sites based on a Dunn's test with Bonferroni's correction for the significance level $(p<0.10)$

\begin{tabular}{llr}
\hline lon or groups of ions & Sites compared & $p$ \\
\hline $\mathrm{SO}_{4}^{2-}$ & Angell with Kvisla & 0.02 \\
$\mathrm{SO}_{4}^{2-}$ & Kvisla with Central & 0.09 \\
$\mathrm{Ca}^{2+}$ & Angell with Kvisla & 0.01 \\
$\mathrm{Cation}^{-}$excluding Na+ & Angell with Kvisla & 0.09 \\
Cation excluding Na+ & Kvisla with Central & 0.10 \\
Anions excluding Cl & Angell with Kvisla & 0.08 \\
Anions excluding Cl- & Kvisla with Central & 0.10 \\
& & \\
\hline
\end{tabular}

lower SI for calcite, dolomite and gypsum than sub-naled water in the Kvisla and Medial moraine sites.

\section{DISCUSSION AND INTERPRETATION}

\section{Interpretation of GPR}

The GPR profiles showed clear distinctions at the interfaces between bedrock, glacier ice, naled ice and liquid water horizons. Figures 3 and 4 illustrate the results of the GPR surveys conducted along and across the naled ice at the Angell section. Here, the naled appeared to have developed in a glacier basin formed on an inclined slope, being configured as a clearly distinguished cone-shaped mound on the surface of the naled. A strong reflection directly below the naled mound indicated the presence of a liquid water reservoir. Two distinct horizons originated from the reservoir, indicating a systematic build-up of naled in association with highly porous ice layers (Fig. 3a).

\section{Naled development during the accumulation season}

Three distinct naled formation types have been described based on the chemical and typological stratification within naled:

Type I naled (exemplified by ice cores A1, A4, K6 and K14), ion concentration increased with depth (Fig. 5). The highest TDS in bottom ice was similar to the lowest TDS in the sub-naled water (lowermost parts of ice cores K6 and K14). This suggests that ice accretion is caused by the freezing of liquid water at the bottom of the naled. For Type I naled, the typical ice core comprised primarily of transparent ice with thin layers of pale white ice (Fig. 6). Type I naledi were the most abundant.

Type II naled (exemplified by ice cores A5 and K4) is characterised by a uniform ice layer structure with no sub-naled water reservoir and the highest ion concentrations in the upper layers (Fig. 5). This type was dominated by both transparent and pale white ice. Yde and others (2012) have previously described a naled ice chemistry similar to that of Type II at Austre Grønfjordbreen in Svalbard, where the majority of the naled formed from ice accretion at the top.

Type III naled (exemplified by ice cores A3 and K13) has a non-uniform structure consisting of layers of high-porosity and low-density large crystals. This suggests that the naled is formed by a combination of different processes affecting formation such as snow metamorphosis (granular ice) or naled melt (candle ice).

To sum up, we suggest that most naledi at Werenskioldbreen grow from the bottom due to ice accretion rather than from the top by freezing of surface water and incorporation of snow.

The high SI of calcite suggests that the precipitation of this mineral leads to the formation of horizontal layers of pale white ice within the naled. However, SI of calcite in ice did not reach oversaturation, possibly due to the dilution effect caused by the presence of a layer of pure ice. Calcite precipitation in ice arises as a consequence of the water chemistry under or at top of the naled. At Werenskioldbreen, water was oversaturated with calcite in few instances, and therefore calcite precipitation was likely to occur. In addition, at the time of formation of the pale white ice layers, small changes in water chemistry $\left(\mathrm{pCO}_{2}, \mathrm{Ca}^{2+}\right)$ or temperature may influence calcite SI leaving it below the saturation level. Calcite, as the dominant precipitating mineral, has previously been found 

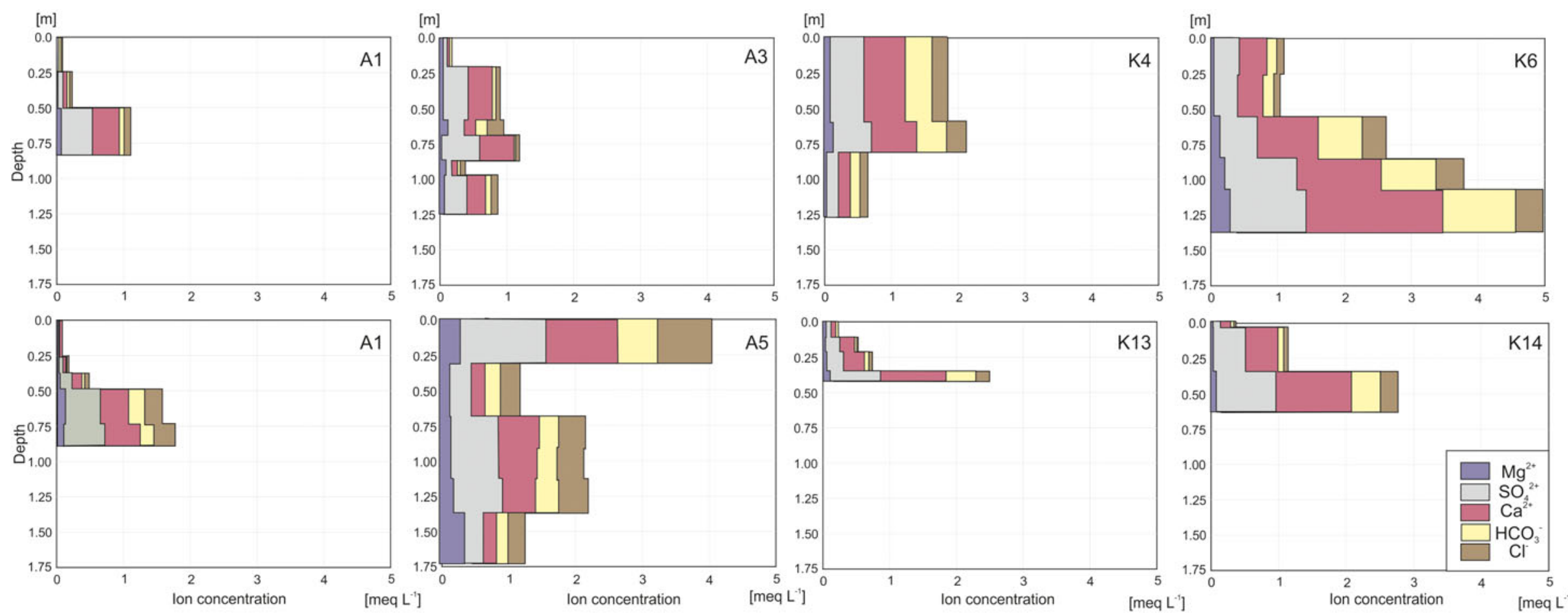

Fig. 5. Chemical stratification (in meq $\mathrm{L}^{-1}$ ) of naled in selected ice cores from the Angell and Kvisla sections of the proglacial area of Werenskioldbreen 


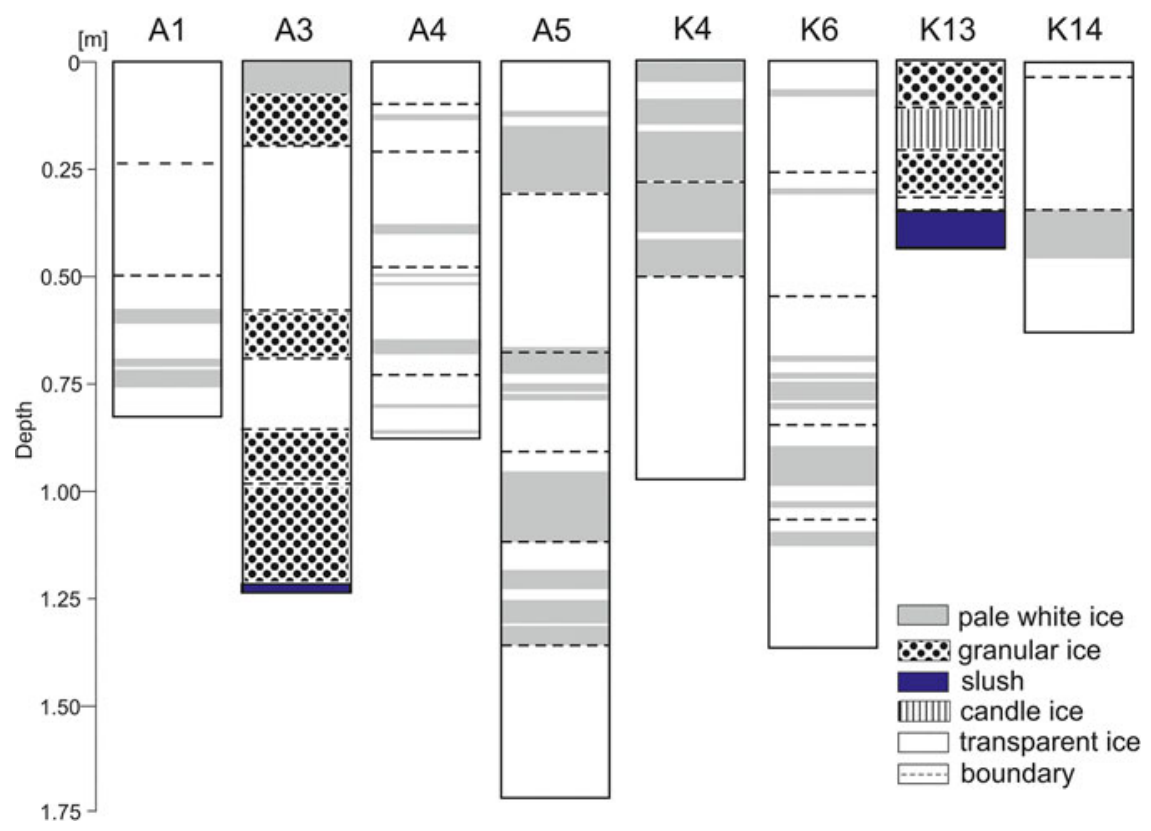

Fig. 6. Stratification of ice profiles in selected ice cores from the Angell and Kvisla sections of the proglacial area of Werenskioldbreen.

on the surface of the naled in the part of the proglacial area, where the Hecla Hoek formation occurs (Drozdowski, 1982). The Sls for gypsum and dolomite were lower than the SI of calcite; however, they might also precipitate in pale white and mixed types of ice. Thus, freezing of highly concentrated water facilitated mineral precipitation in pale white ice. Calcite precipitation appeared to take place in the distal part of the naled, where pale white ice dominated (e.g. in the A5 and $\mathrm{K} 4$ ice cores). Moreover, similar ion concentrations in subnaled water in the Angell site and in the upper part of ice core A5 indicate refreezing of highly concentrated water released from naled. Close to cracks in the naled (A1, K6), the presence of transparent and mixed types of naled ice indicated limited or no mineral precipitation (Fig. 6). This is in contrast to previous observations, where calcite precipitation has been observed to occur close to naled mounds (Wadham and others, 2000; Bukowska-Jania, 2007). However, this is not the case at Werenskioldbreen, as no elevated concentrations of calcite-derived ions $\left(\mathrm{Ca}^{2+}, \mathrm{HCO}_{3}^{-}\right)$ were observed near to the naled mound. We found that successive outflow of water from cracks in the naled caused an increase in the ion concentrations of the naled ice, with mineral precipitation (primarily in the form of calcite) occurring in distal parts of the naled.

No naled was observed in the Angell section on 9 February 2013; however, a naled mound was found on 24
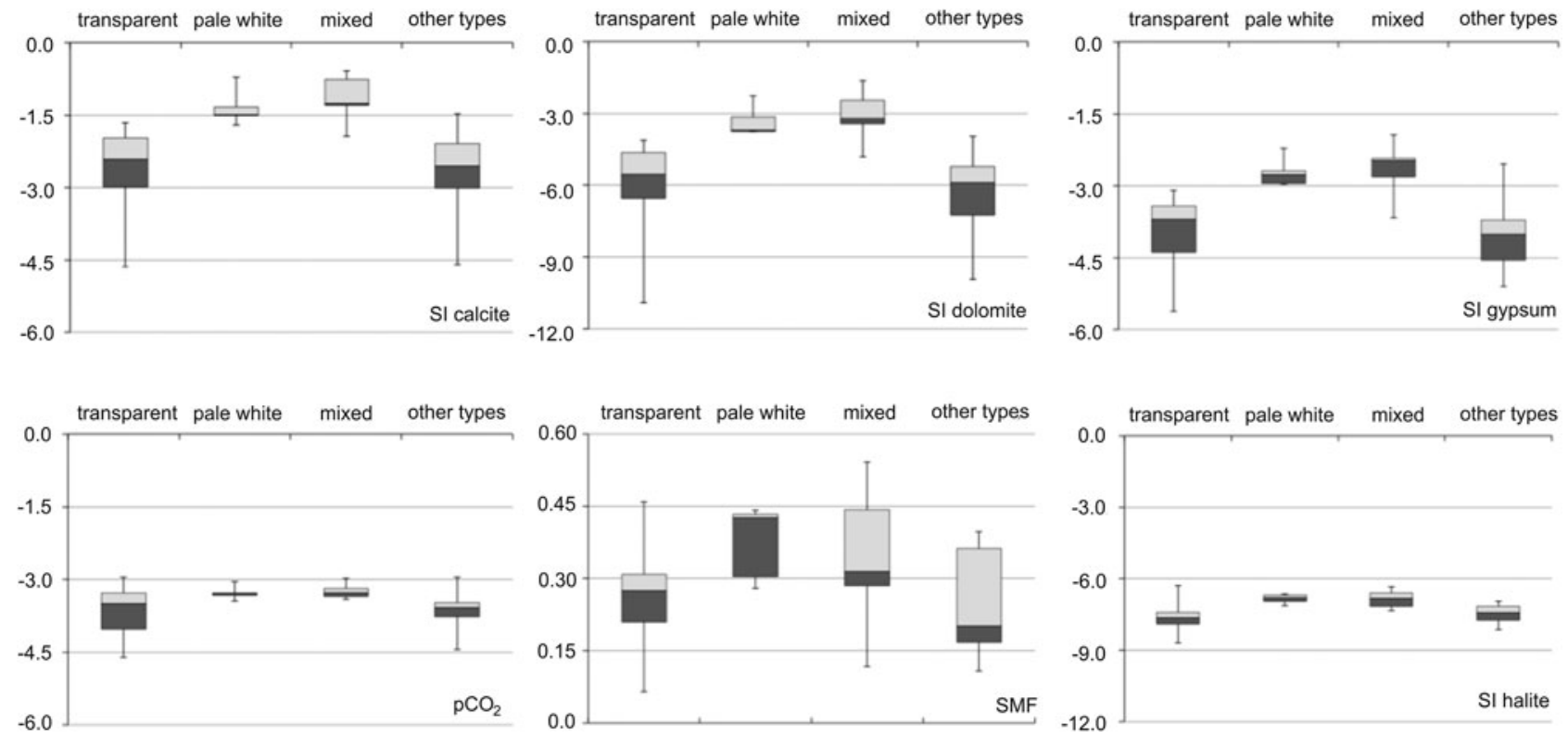

Fig. 7. Saturation indices with respect to calcite, dolomite, gypsum, halite, and sulphate mass fraction (SMF) and pCO $\mathrm{CO}_{2}$ for four types of naled ice. The group "mixed" represents the occurrence of pale white and transparent ice within a single layer, whereas candle ice, granular ice and slush ice are combined in the group "other types". Note the different scales on the y-axes. 
Table 4. Ion concentrations (in meq $\mathrm{L}^{-1}$ ) of sub-naled water in the proglacial area of Werenskioldbreen

\begin{tabular}{|c|c|c|c|c|c|c|c|c|c|c|c|c|c|c|c|c|c|}
\hline \multirow{2}{*}{$\frac{\text { Site }}{\text { Angell }}$} & \multirow{2}{*}{$\begin{array}{l}\text { Statistics } \\
\text { Mean }\end{array}$} & \multicolumn{2}{|c|}{$\mathrm{HCO}_{3}^{-}$} & \multicolumn{2}{|c|}{$\mathrm{SO}_{4}^{2-}$} & \multicolumn{2}{|c|}{$\mathrm{Cl}^{-}$} & \multicolumn{2}{|c|}{$\mathrm{Ca}^{2+}$} & \multicolumn{2}{|c|}{$\mathrm{Mg}^{2+}$} & \multicolumn{2}{|c|}{$\mathrm{K}^{+}$} & \multicolumn{2}{|c|}{$\mathrm{Na}^{+}$} & \multicolumn{2}{|c|}{ TDS } \\
\hline & & 1.52 & & 0.73 & & 0.33 & & 1.17 & & 0.89 & & 0.06 & & 0.45 & & 5.2 & \\
\hline \multirow[t]{3}{*}{$N=3$} & Median & 1.52 & & 0.74 & & 0.32 & & 1.16 & & 0.92 & & 0.06 & & 0.46 & & 5.2 & \\
\hline & $\mathrm{SD}$ & 0.15 & & 0.05 & & 0.02 & & 0.05 & & 0.09 & & 0.01 & & 0.03 & & 0.3 & \\
\hline & Min-max & 1.38 & 1.67 & 0.68 & 0.77 & 0.31 & 0.35 & 1.13 & 1.23 & 0.79 & 0.96 & 0.06 & 0.07 & 0.41 & 0.47 & 4.9 & 5.5 \\
\hline Kvisla & Mean & 2.01 & & 1.86 & & 0.56 & & 2.40 & & 1.33 & & 0.04 & & 0.64 & & 8.9 & \\
\hline \multirow[t]{2}{*}{$N=9$} & Median & 1.92 & & 1.72 & & 0.55 & & 2.21 & & 1.24 & & 0.04 & & 0.68 & & 8.4 & \\
\hline & Min-max & 0.87 & 2.86 & 0.37 & 3.64 & 0.21 & 1.19 & 0.91 & 4.06 & 0.24 & 2.60 & 0.01 & 0.06 & 0.13 & 1.21 & 3.0 & 14.0 \\
\hline Central & Mean & 2.22 & & 2.67 & & 0.96 & & 3.34 & & 1.33 & & 0.19 & & 1.14 & & 11.9 & \\
\hline \multirow[t]{3}{*}{$N=4$} & Median & 2.23 & & 2.63 & & 1.04 & & 3.24 & & 1.27 & & 0.18 & & 1.19 & & 11.3 & \\
\hline & SD & 1.20 & & 1.85 & & 0.53 & & 2.21 & & 0.83 & & 0.16 & & 0.68 & & 7.4 & \\
\hline & Min-max & 1.03 & 3.39 & 0.84 & 4.59 & 0.28 & 1.50 & 1.19 & 5.70 & 0.49 & 2.29 & 0.05 & 0.36 & 0.31 & 1.86 & 5.4 & 19.8 \\
\hline$M M$ & Mean & 2.25 & & 2.41 & & 0.81 & & 2.68 & & 1.70 & & 0.05 & & 0.93 & & 10.8 & \\
\hline \multirow[t]{2}{*}{$(N=3)$} & Median & 2.15 & & 2.36 & & 0.82 & & 2.67 & & 1.74 & & 0.04 & & 0.94 & & 10.8 & \\
\hline & Min-max & 2.10 & 2.49 & 2.27 & 2.59 & 0.75 & 0.88 & 2.56 & 2.81 & 1.53 & 1.82 & 0.04 & 0.07 & 0.91 & 0.94 & 10.8 & 11.0 \\
\hline
\end{tabular}

MM, Medial moraine; TDS, total dissolved solids.

March 2013. A large ice slab had detached from just below the naled crest and been transported $\sim 60 \mathrm{~m}$ downstream (Fig. 2b). A similar phenomenon has previously been observed in Siberian permafrost (Carey, 1973). Hydrostatic pressure built up during late spring favoured by the high inclination of the bedrock (Fig. 3b) eventually caused breakup of the ice below the naled mound. The GPR profiles showed that the water reservoir was trapped in the naled ice, suggesting an increase of water pressure over time during naled formation (Fig. 4). The two reflectors originating from the water reservoir observed in the GPR profiles might indicate water pushing into the weaker layers in the naled ice due to high hydrostatic pressure (Figs $3 a$ and 4). Hydrostatic pressures also influence the sides, but not the crest, of the naled mound, forming a 'parasitic' outflow.

\section{Subglacial drainage system during the accumulation season}

The diversity of the solute compositions of sub-naled water is in accordance with the spatial variability TDS and ion concentrations in river water, previously described from the

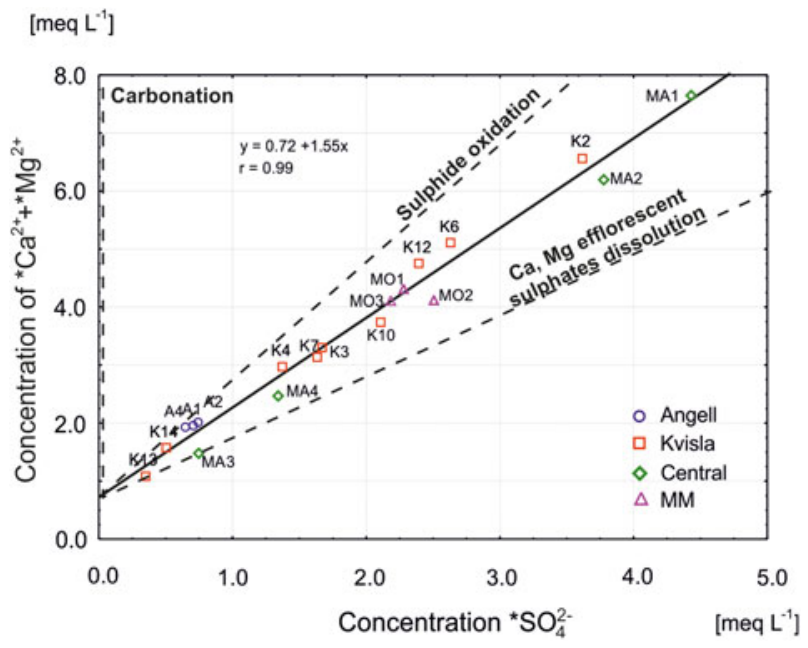

Fig. 8. Relationship between ${ }^{*} \mathrm{Ca}^{2+}+* \mathrm{Mg}^{2+}$ and $* \mathrm{SO}_{4}^{2-}$ for subnaled water. MM denotes Medial moraine.
Werenskioldbreen basin (Krawczyk and Wach, 1993; Krawczyk and others, 1997).

Despite similar ion concentrations, different chemical weathering conditions affected the water chemistry in the Angell section and the remote proglacial naled in the Kvisla section (K13, K14). Both sites are located on a sandur plain with weak connection to the subglacial drainage system. These sites had low SMF suggesting that not only may sulphide oxidation influence the solute composition but also there are other processes. At the Kvisla sites, $\mathrm{pCO}_{2}$ values close to atmospheric levels (-3.5) showed dissolution of Ca-Mg efflorescent salts (Szynkiewicz and others, 2013) and carbonation. At the Angell sites, $\mathrm{pCO}_{2}$ higher than the atmospheric level suggested water enrichment in $\mathrm{CO}_{2}$ during freezing. We propose that sulphide oxidation predominates in the Angell subglacial system, whereas carbonation of carbonates and $\mathrm{Ca}-\mathrm{Mg}$ salts dissolution occurs in the Kvisla subglacial system.

The spatial distribution of the naled reflected the position of subglacial outflows during the summer despite of constant changes in the Werenskioldbreen subglacial drainage system

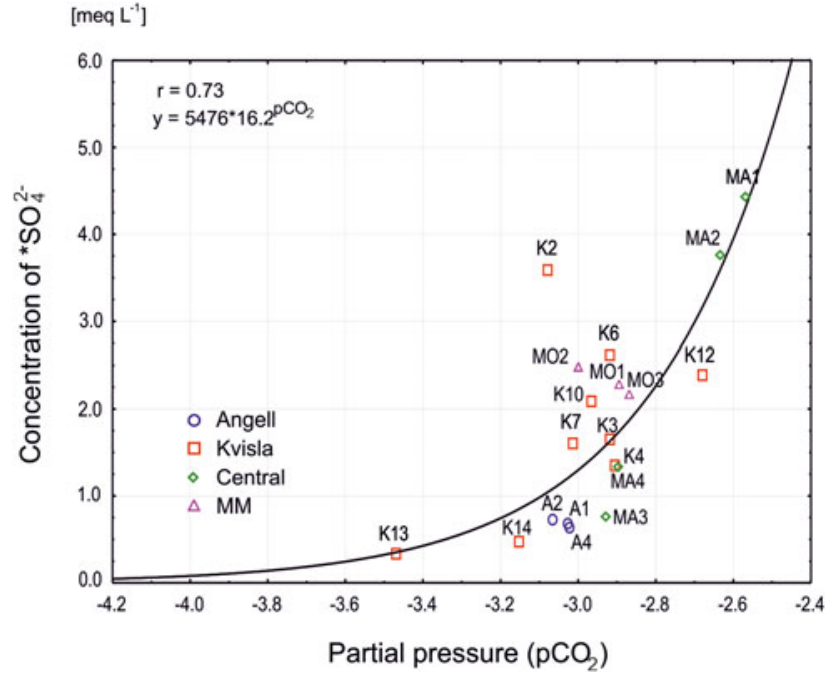

Fig. 9. Relationship between $* \mathrm{SO}_{4}^{2-}$ and $\mathrm{pCO}_{2}$ for sub-naled water samples. MM denotes Medial moraine. 

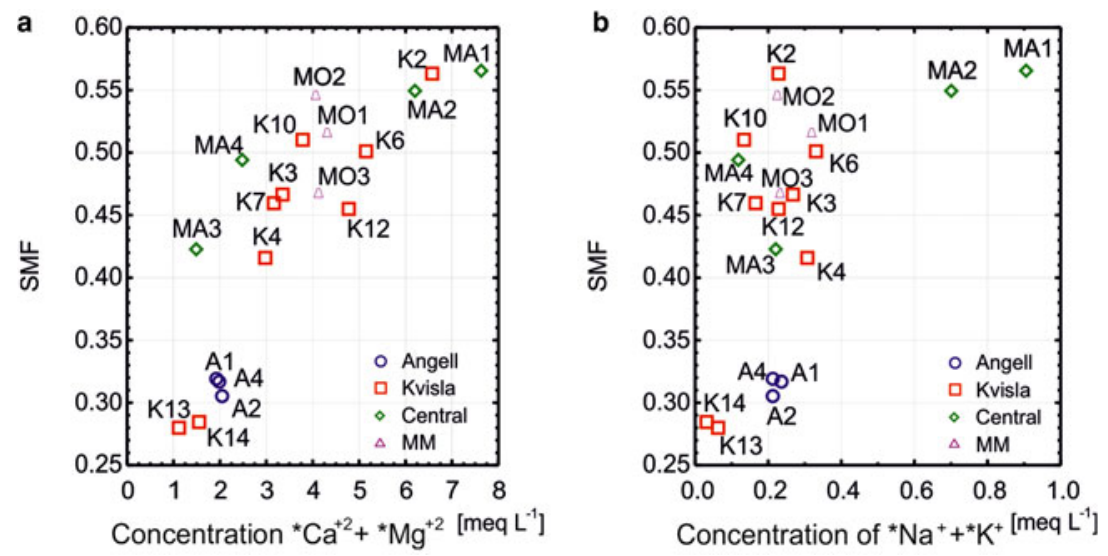

Fig. 10. Relationship between sub-naled water chemistry: (a) sulphate mass fraction vs. ${ }^{*} \mathrm{Ca}^{2+}+{ }^{*} \mathrm{Mg}^{2+}$ and (b) sulphate mass fraction vs. ${ }^{*} \mathrm{Na}^{+}+{ }^{*} \mathrm{~K}^{+}$. MM denotes Medial moraine.

(Pälli and others, 2003; Piechota and others, 2012). Our data show that water from beneath the naled in the central part (MA1, MA2) had the highest concentrations of major ions and SMF close to 0.5 , suggesting that sulphide oxidation is dominant. The naled in the Central part of the glacier forefield is small in size compared with the naledi observed at the Kvisla and Medial moraine sites. Thus, we envisage that the water supply to the Central part of the glacier front (MA1, MA2) is derived from a subglacial network with an elevated chemical weathering rate but low water flow or low efficient drainage.

Naled and subglacial outflows at the end of the Medial moraine (MO1-4) have never been reported in previous research (e.g. Krawczyk and Wach, 1993; Bukowska-Jania, 2007). At the end of the Medial moraine, the naled was more extensive than in the Central part, indicating a high water delivery during the accumulation season. The TDS in the Medial moraine naled is similar to the TDS in the Central naled, suggesting high rates of chemical weathering. Baranowski (1968) reported observations of three levels of channels at the end of the Medial moraine and drainage modelling by Pälli and others (2003) indicated the existence of a conduit system under the Medial moraine. Our hydrochemical data support that a subglacial conduit under the Medial moraine is highly probable, and might be linked to other naledi. The presence of four separate naledi in the proglacial zone suggests that the subglacial drainage system was divided into a few tributaries near the glacier front. Perennial changes in the position of the main outflow during the ablation season suggest one tributary is preferentially used when the meltwater production is high. This reflects the structure of a distributed drainage system such as linked cavities during the accumulation season (Fountain and Walder, 1998). Water flow is constrained to a channel under the Medial moraine, but close to the glacier front water is routed towards the naled sites. We suggest that under the Medial moraine a distributed drainage system is active during accumulation season with a main conduit that splits into several tributaries near the glacier front.

\section{Chemical processes during the accumulation season}

The strong correlation between $\left({ }^{*} \mathrm{Ca}^{2+}+{ }^{*} \mathrm{Mg}^{2+}\right)$ and $\left({ }^{*} \mathrm{SO}_{4}^{2-}\right)$ suggests that sulphide oxidation and $\mathrm{Ca}-\mathrm{Mg}$ efflorescent salts dissolution, operated in the subglacial drainage system during the accumulation season. The ice and sub-naled water chemistry in the Angell section was clearly different to the chemistry at other sites (Tables 2 and 3), suggesting a weaker connectivity to the subglacial drainage system. The high $\left({ }^{*} \mathrm{Ca}^{2+}+{ }^{*} \mathrm{Mg}^{2+}\right):\left(* \mathrm{Na}^{+}+{ }^{*} \mathrm{~K}^{+}\right)$index in the Kvisla section revealed that carbonate chemical weathering was significantly higher than silicate weathering. However, the carbonate weathering was still pronounced in the Angell section, although silicate weathering was important. Dissolution of carbonates, which is shown by high SI for calcite and dolomite, decreased southwards in the proglacial area. This is consistent with the occurrence of carbonates in schists in the northern and north-eastern margin of the glacier (Czerny and others, 1993). On the other hand, rocks in the southern part consist of amphibole minerals (Czerny and others, 1993). Silicate dissolution appears to be coupled with sulphide oxidation, as the concentration of $* \mathrm{Na}^{+}+{ }^{*} \mathrm{~K}^{+}$ increased with SMF.

A strong relationship $(r>0.7)$ between $* \mathrm{SO}_{4}^{2-}$ and $\mathrm{pCO}_{2}$ suggested that sulphide oxidation was an important $\mathrm{H}^{+}$ donor, increasing $\mathrm{pCO}_{2}$ above atmospheric levels (-3.5) (Tranter and others, 2002). Also, in sub-naled waters the slope of the curve showing the relation between $\left({ }^{*} \mathrm{Ca}^{2+}+\right.$ $\left.{ }^{*} \mathrm{Mg}^{2+}\right)$ and $\left({ }^{*} \mathrm{SO}_{4}^{2-}\right)$ was close to 2.0 , confirming that sulphide oxidation was the main chemical weathering reaction

Table 5. Mean saturation indices and ion ratios in sub-naled water

\begin{tabular}{|c|c|c|c|c|c|c|}
\hline Site & SIhal & SIcal & SIdol & Slgyp & $\left(\mathrm{Ca}^{2+}+\mathrm{Mg}^{2+}\right): \mathrm{Cl}^{-}$ & $*\left(\mathrm{Ca}^{2+}+\mathrm{Mg}^{2+}\right): *\left(\mathrm{Na}^{+}+\mathrm{K}^{+}\right)$ \\
\hline Angel $(N=3)$ & -8.4 & -0.7 & -1.9 & -2.3 & 6.3 & 9.0 \\
\hline Kvisla $(N=9)$ & -8.2 & -0.3 & -1.3 & -1.8 & 7.6 & 22.5 \\
\hline Central $(N=4)$ & -7.7 & -0.5 & -1.7 & -1.6 & 5.4 & 11.4 \\
\hline$M M(N=3)$ & -7.7 & -0.2 & -1.0 & -1.6 & 5.4 & 16.3 \\
\hline
\end{tabular}

MM, Medial moraine; SIhal, SIcal, SIdol, SIgyp refer to the saturation indices of halite, calcite, dolomite and gypsum, respectively. 
(Wadham and others, 2010). This relationship also showed that the $\mathrm{Ca}-\mathrm{Mg}$ efflorescent salts dissolution (Szynkiewicz and others, 2013) was likely to occur; however, a low gypsum SI revealing pronounced under saturation suggested that $\mathrm{Ca}-\mathrm{Mg}$ efflorescent salts dissolution was not very intensive. The values of SIs for calcite and dolomite indicated the presence of dissolved carbonates leading to their precipitation. Transparent ice exhibited low SI values for all minerals compared with pale white ice. Our data also show that transparent and pale white ice form as a result of freezing of water with a low solute concentration and highly saturated water (known also from laboratory experiments as 'brine naledi' (Pollard, 2005).

Our results support previous work by Pulina and others (1984) who suggested that $\sim 0.710^{6} \mathrm{~m}^{3}$ of water was stored in the subglacial system of Werenskioldbreen at the beginning of the winter season 1979/80, and Pälli and others (2003) who found a reservoir beneath Werenskioldbreen. More recently, Majchrowska and others (2015) showed that the mean ratio of runoff:ablation for the ablation seasons 2007-12 was $43 \%$, suggesting that interannual water storage was very likely. Interannual water storage establishes conditions that enhance subglacial chemical weathering and biological activity. Sulphide oxidation, which was observed in sub-naled water at Werenskioldbreen, may enrich subglacial water in nutrients (i.e. bioavailable iron), during the accumulation season and be released during the following ablation season. Subglacial chemical weathering during the accumulation season may be an important source of solutes exported during the ablation season because $\sim 40 \%$ of the ablation water appears to be stored in the subglacial drainage system.

\section{CONCLUSIONS}

Here, we provide a novel dataset showing the complexity of glacier-derived naled in front of Werenskioldbreen, Svalbard. The data include GPR surveys, and naled ice and sub-naled water chemistry samples collected during the accumulation season. During the accumulation season, the naled developed mostly by ice accretion from the bottom, influencing the ice chemistry in a bottom-up manner. The presence of thick naled in front of a Medial moraine is likely connected to the existence of a distributed subglacial drainage system with a main channel within or beneath the Medial moraine that splits into a number of tributaries near to glacier front. Sulphide oxidation was a widespread $\mathrm{H}^{+}$donor for carbonate dissolution in the subglacial drainage system during the accumulation season, accompanied by $\mathrm{Ca}-\mathrm{Mg}$ sulphate dissolution.

\section{ACKNOWLEDGEMENTS}

We thank Maciej Benedyk and Tomasz Wawrzyniak (Institute of Geophysics Polish Academy of Sciences) and the Hornsund Polish Polar Station (Institute of Geophysics Polish Academy of Sciences) staff for delivering air temperature data. This work was supported by three research projects funded by the Research Council of Norway (Arctic Field Grant 2013, no. 227580) and the National Science Centre in Poland (N N306 179737 and N N306 792040). This research was conducted as part of scientific programme of the XXXV Polish Polar Expedition to Hornsund from Institute of Geophysics Polish Academy of Sciences. The publication has been financed from the funds of the Leading National
Research Centre (KNOW) received by the Centre for Polar Studies for the period 2014-2018.

\section{REFERENCES}

Åkerman J (1982) Studies on naledi (icings) in West Spitsbergen. In French HM ed. Proceedings of the 4th Canadian permafrost conference. National Research Council of Canada, Ottawa, Canada, 189-202

Baranowski S (1968) Tension cracks and ice tunnels in the terminal part of the median moraine of Werenskioldbreen, Vestspitsbergen. In Birkenmajer K ed. Polish Spitsbergen expeditions 1957-1960. Wydawnictwa Geologiczne, Warszawa, Poland, 321-328

Baranowski S (1982) Naled ice in front of some Spitsbergen glaciers. J. Glaciol., 28(98), 211-214

Bukowska-Jania E (2007) The role of glacier system in migration of calcium carbonate on Svalbard. Pol. Polar Res., 28(2), 137-155

Bukowska-Jania E and Szafraniec J (2005) Distribution and morphometric characteristics of icing fields in Svalbard. Polar Res., 24(1-2), 41-53

Carey KL (1973) Icings developed from surface water and ground water. Corps of Engineers, U.S. Army Cold Regions Research and Engineering Laboratory, Hanover, New Hampshire

Czerny J, Kieres A, Manecki M and Rajchel J (1993) Geological map of the SW part of Wedel-Jarlsberg Land, Spitsbergen. Institute of Geology and Mineral Deposits, University of Mining and Metallurgy, Kraków, Poland

Drozdowski E (1982) Calcite deposits precipitated during formation of icings. Acta Univer. Wrat., 525(4), 39-48

Fountain AG and Walder JS (1998) Water flow through temperate glaciers. Rev. Geophys., 36(3), 299-328 (doi: 10.1029/ 97RG03579)

Gokham VV (1987) Distribution and conditions of formation of glacial icings on Spitsbergen. Polar Geogr. Geol., 11(4), 249-260

Grabiec M, Budzik T and Głowacki P (2012) Modelling and hindcasting of the mass balance of Werenskioldbreen (Southern Svalbard). Arctic Antarct. Alp. Res., 44(2), 164-179.

Grześ M and Sobota I (2000) Winter snow accumulation and discharge from the Waldemar Glacier, northwestern Spitsbergen in 1996-1998. Pol. Polar Res., 21(1), 19-32

Hagen JO, Liestol O, Roland E and Jorgensen T (1993) Glacier atlas of Svalbard and Jan Mayen. Norsk Polarinstitutt, Oslo

Hodgkins R, Tranter M and Dowdeswell JA (2004) The characteristics and formation of a High-Arctic proglacial icing. Geogr. Ann. ser. A, 86(3), 265-275 (doi: 10.1111/j.0435-3676. 2004. 00230.x)

Holland HD (1978) The chemistry of the atmosphere and oceans. Wiley Intersciece, New York, 351 pp

Kies A, Nawrot AP, Tosheva Z and Jania J (2011) Natural radioactive isotopes in glacier meltwater studies. Geochem. J., 45(6), 423-429

Krawczyk W and Wach J (1993) Winter outflow of waters from the Werenskiold glacier in the hydrological year 1985/1986. In Repelewska-Pekalowa J and Pẹkala K eds. XX polar symposium main impact on polar environment. Wydawnictwo Uniwersytetu Marii Curie-Skłodowskiej, Lublin, Poland, 403-411

Krawczyk W, Pulina M and Rehak J (1997) Similarity between the hydrologic system of the Werenskiold Glacier (SW Spitsbergen) and a karst. In Proceedings of the 12th International Congress of Speleology, La Chaux-de-Fonds, Switerland, 493-496 (Sympozium 7 Physical Speleology \& Symposium 8 Karst Geomorphology)

Majchrowska E, Ignatiuk D, Jania J, Marszałek $\mathrm{H}$ and Wasik M (2015) Seasonal and interannual variability in runoff from the Werenskioldbreen catchment, Spitsbergen. Pol. Polar Res., 36 (3), 197-224 (doi: 10.1515/popore-2015-0014)

Moorman BJ and Michel FA (2000) Glacial hydrological system characterization using ground-penetrating radar. Hydrol. Processes, 14(15), 2645-2667 
Olszewski A (1982) Icings and their geomorphological significance exemplified from Oscar II Land and Prins Karls Forland, Svalbard. Acta Univer. Nicolai Copernici Geografia, 51, 91-122

Pälli A, Moore JC, Jania J, Kolondra L and Głowacki P (2003) The drainage pattern of Hansbreen and Werenskioldbreen, two polythermal glaciers in Svalbard. Polar Res., 22(2), 355-371

Parkhurst DL and Appelo CAJ (2013) Description of input and examples for PHREEQC version 3 - a computer program for speciation, batch-reaction, one-dimensional transport, and inverse geochemical calculations. In Survey USGS ed. U.S. geological survey techniques and methods. U.S. Geological Survey, Denver, Colorado, US, 497 (A43)

Piechota AM, Sitek S, Ignatiuk D and Piotrowski JA (2012) Reconstructing subglacial drainage of Werenskiold Glacier (SW Spitsbergen) based on numerical modelling. Rekonstrukcja drenazu subglacjalnego lodowca Werenskiolda (SW Spitsbergen) na podstawie modelowania numerycznego. Biul. Państ. Instyt. Geolog., 451, 191-202

Plewes LA and Hubbard B (2001) A review of the use of radio-echo sounding in glaciology. Prog. Phys. Geogr., 25(2), 203-236 (doi: 10.1191/030913301668581943)

Pollard WH (2005) Icing processes associated with high Arctic perennial springs, Axel Heiberg Island, Nunavut, Canada. Permafrost Periglac., 16(1), 51-68 (doi: 10.1002/ppp.515)

Pulina M (1984) The effects of cryochemical processes in the glaciers and the permafrost in Spitsbergen. Pol. Polar Res., 5(3-4), 137-163

Szynkiewicz A, Modelska M, Buczyński S, Borrok DM and Merrison JP (2013) The polar sulfur cycle in the
Werenskioldbreen, Spitsbergen: possible implications for understanding the deposition of sulfate minerals in the North Polar Region of Mars. Geochim. Cosmochim. Acta, 106, 326-343 (doi: 10.1016/j.gca.2012.12.041)

Tranter M and 5 others (2002) Geochemical weathering at the bed of Haut glacier d'Arolla, Switzerland - a new model. Hydrol. Processes, 16(5), 959-993 (doi: 10.1002/hyp.309)

Wadham JL, Hodson AJ, Tranter M and Dowdeswell JA (1998) The hydrochemistry of meltwaters draining a polythermal-based, high Arctic glacier, south Svalbard: I. The ablation season. Hydrol. Processes, 12(12), 1825-1849 (doi: 10.1002/(sici)10991085(19981015)12:12<1825::aid-hyp669>3.0.co;2-r)

Wadham JL, Tranter M and Dowdeswell JA (2000) Hydrochemistry of meltwaters draining a polythermal-based, high-Arctic glacier, south Svalbard: II. Winter and early Spring. Hydrol. Processes, 14(10), 1767-1786 (doi: 10.1002/1099-1085(200007)14: $10<1767:$ :aid-hyp $103>3.0 . c 0 ; 2-q)$

Wadham JL and 6 others (2010) Hydro-biogeochemical coupling beneath a large polythermal Arctic glacier: implications for subice sheet biogeochemistry. J. Geophys. Res., 115(4), F04017 (doi: 10.1029/2009jf001602)

Yde JC and Knudsen NT (2005) Observations of debris-rich naled associated with a major glacier surge event, Disko Island, West Greenland. Permafrost Periglac., 16(4), 319-325 (doi: 10.1002/ ppp.533)

Yde JC and 6 others (2012) Chemical and isotopic characteristics of a glacier-derived naled in front of Austre Grønfjordbreen, Svalbard. Polar Res., 31(Suppl.) (doi: 10.3402/polar.v31 i0.17628) 